\title{
AKÁCFA GÁZOSÍTÁSÁNAK VIZSGÁLATA VÁLTOZÓ ÜZEMI PARAMÉTEREK MELLETT
}

\section{INSPECTING THE GASIFCATION PROCESS DONE ON THE ACACIA-TREE UNDER INDUSTRIAL CONDITIONS}

\author{
Bodnár István ${ }^{1}$, Iski Patrik², Skribanek Ádám ${ }^{3}$ \\ ${ }^{1}$ Egyetemi adjunktus, Miskolci Egyetem, Gépészmérnöki és Informatikai Kar, Elekt- \\ rotechnikai és Elektronikai Intézet, cím: Magyarország, 3515 Miskolc- Egyetemvá- \\ ros; Telefon / Fax: +36 46565 142, vegybod@uni-miskolc.hu \\ ${ }^{2}$ BSc hallgató, Miskolci Egyetem, Gépészmérnöki és Informatikai Kar, Elektrotech- \\ nikai és Elektronikai Intézet, cím: Magyarország, 3515 Miskolc- Egyetemváros; Te- \\ lefon / Fax: +36 46565 142, iskip95@gmail.com \\ ${ }^{3}$ BSc hallgató, Miskolci Egyetem, Gépészmérnöki és Informatikai Kar, Elektrotech- \\ nikai és Elektronikai Intézet, cím: Magyarország, 3515 Miskolc- Egyetemváros; Te- \\ lefon / Fax: +36 46565 142, skribike@gmail.com
}

\begin{abstract}
This paper presents a thermos-kinetical modelling on the gasification process done on the acacia-tree under varying industrial circumstances and different humidity levels. The gasification does not produce flue gas, but due to imperfect burning synthesis gas which is rich in flammable components $\left(\mathrm{CO}_{2}\right.$ and $\mathrm{H}_{2}$ ). The chemical structure of this gas is depends on the components of the fuel and the humidity levels but greatly affected by the technological parameters, also. Such as parameters are the pressure and the temperature, as well as the air-ratio. The study introduces the changing in the conjunction, the fuel value and the reaction efficiency due to varying gasification temperature and pressure. Rising temperature results in improved efficiency, while the higher pressure worsens the reaction efficiency. However at higher temperature intervals the effect of the pressure is neglect able.
\end{abstract}

Keywords: acacias, gasification, temperature, air-ratio, reaction efficiency

\section{Összefoglalás}

A dolgozat az akácfa gázosításának thermokinetikai modellezésével kapott eredményit ismerteti, változó üzemi paraméterek és fanedvesség esetében. A gázosítás egy olyan folyamat, amely során a tökéletlen égésnek köszönhetően nem füstgáz, hanem éghető komponensekben (CO2 és H2) gazdag szintézisgáz képződik. A keletkező szintézisgáz kémiai összetételét a tüzelőanyag összetételén és nedvességtartalmán felül, a technológiai paraméterek is jelentős mértékben befolyásolják. Ilyen paraméter az üzemi nyomás, a gázosítási hőmérséklet, valamint a légfelesleg-tényező. A tanulmány a gázosítási hőmérséklet és az üzemi nyomás változtatására bekövetkező összetétel-, fütőérték- és reakcióhatásfokváltozást mutatja be. Míg a hőmérséklet növelése javuló hatásfokot eredményez, addig a nyomás növekedése a gázosítás reakció-hatásfokának romlását okoz. Azonban nagyobb hőmérséklettartományokban a nyomásváltozás hatása elhanyagolható.

Kulcsszavak: akácfa, gázositás, hömérséklet, légfelesleg-tényezö, reakció hatásfok 


\section{Bevezetés}

Napjaink egyik kulcsfontosságú kutatási területe az energetika, ami az energiatermelés- és felhasználás, valamint a hatékonyságnövelés köré épül. A hőenergia termelés kapcsán gyakran hallani a gázosítási technológiáról, első sorban a faelgázosító kazánok esetében. Azonban a gázosítás nem csak a hőenergia, hanem a villamosenergiatermelés folyamatába is bevonható, mivel a gázosítás fő terméke az éghető szintézisgáz, amely gázmotorokban, és gázturbinákban nagy hatásfokkal alkalmazható villamos-energia termelésére. A gázüzemü erőgépek gyakran kényesek a bemenő gáz összetételére, minőségi paramétereire, ezért elkerülhetetlen a fagázosítás vizsgálata. Mindemellett a fagázosítás lehetőséget biztosít tüzifa, illetve biomassza alapú gyorsindítású erőművek létesítésére.

\section{A gázosítás történeti áttekintése}

A gázosítás az egyik legrégebben alkalmazott eljárás szilárd halmazállapotú fosszilis és megújuló energiahordozók éghető szintézisgázzá és folyékony üzemanyaggá történő átalakítására. A gázosítást elsőként Thomas Shirley alkalmazta hidrogén előállítására 1659-ben. Az első szabadalmat 1788-ban Robert Gardner nyújtotta be, ezzel kezdetét vette a gázosítás térhódítása. Ipari alkalmazása William Murdoch nevéhez füződik, és 1798-ban kezdődött Angliában valamint Franciaországban [1].

Kezdetben fából és szénből állítottak elő éghető gázokat (fagáz és széngáz), amit főleg fütési és közvilágítási célokra alkalmaztak. 1850-re a technológia olyan fejlettségi szintet ért el, ami lehetővé tette, hogy London közvilágításának 75\%-át, az ilyen módon előállított mesterséges gázokkal oldják meg. Néhány ével később a gázosítási technológia megjelent az Amerikai Egyesült Államokban is, és 1920-ra a legtöbb városban (pl.: Chicago, Denver) fütésre, valamint világításra használták a gázgyárakban előállított szintézisgázokat [2].

A texasi olajmezők felfedezését követően 1930-ban kiépült az első földgázvezeték Denverben, ami megszüntette a szintézisgáz egyeduralmát. Az északi tenger alatt lévő olajmező felfedezését követően idővel Európában is a feledés homályába merültek a gázgyárak. Ugyan, az utolsót 1970-ben bontották le Angliában, de még napjainkban is található müködő rendszer a harmadik világbeli országokban [1].

A belső égésű motorok megjelenésével a gázosítást alternatív üzemanyag előállítására is alkalmazni kezdték. Az első fagázzal müködő autót 1901-ben Thomas Hugh Parker tervezte és építette meg, azonban elterjedésére mintegy harminc évet kellett várni. Az 1930-as években a hadiipar rohamos fejlődése és a második világháború okozta nyersanyaghiány alternatív technológiák alkalmazását tették szükségessé az üzemanyagiparban is. A II. világháború alatt a Szövetségesek és a Szovjetunió nem szállított kőolajat a németek által megszállt európai országokba. A helyi kismértékü kitermelést a német hadsereg (Wehrmacht) használta fel. Mivel még a hadiipar számára sem volt elegendő üzemanyag, a Wehrmacht még fagáz-üzemü tankokkal is kísérletezett, amelyek bevetésére végül körülményes üzemeltetésük miatt nem kerülhetett sor. A II. világháború végére, csupán Németországban körülbelül félmillió fagázüzemü jármü üzemelt [1]. Európában egymillióra volt tehető az ilyen jármüvek száma. A megszállt Dániában a civil jármüvek és mezőgazdasági gépek 95\%-a fagázzal üzemelt [2].

A tűzifa gázosítása során keletkező szintézisgáz kémiai összetétele és energiatartalma megfelelö volt ahhoz, hogy az akkori, kezdetleges belsőégésű motorok (Otto-motorok) hajtóanyagául szolgáljon [1]. Néhány évtizeddel később a gázosítás tovább-fejlesztett változatát a hulladékgazdálkodásban és az erőmü-energetikában is 
alkalmazni kezdték. Külön szerelőmühelyeket alakítottak ki, hogy a már forgalomban lévő hagyományos autókat át tudják alakítani fagáz üzeművé, továbbá olyan üzemanyagtöltő állomások jöttek létre, ahol megfelelő méretüre aprított tüzifát lehetett vásásrolni.

A gázosítás az anyagok gyors höbontásán alapuló, parciális oxidációval lejátszódó folyamat, amely így a tökéletes égéshez szükséges elméleti oxigénmennyiséghez képest kisebb oxigénszükséglettel rendelkezik [2]. Az alapanyagban található szerves vegyületek részleges oxidációja közben szintézisgáz szabadul fel, ami akár nyersanyagként, vegyipari szintézisekben, vagy tüzelőanyagként hasznosítható [1].

A folyamat érzékenysége miatt fontos, hogy a beadagolt tüzelőanyag jellegzetességei (méret, nedvességtartalom, konzisztencia) bizonyos elöre meghatározott határértékek közt maradjon [3]. Az érzékenység hatása jellemzően az energetikai- és a környezeti hatékonyságban jelentkezik.

Az eljárás legfőbb célja a hulladék ártalmatlanítása mellett a legnagyobb gázkihozatal, amihez az optimális energetikai hatásfok elérése társul. A gázosítás során előállított szintézisgáz hidrogénben és szénmonoxidban gazdag gázelegy, ami a gázosító közegtöl függően más, energetikailag inert összetevőket is tartalmazhat. A legygyakrabban előforduló éghetetlen komponens a szén-dioxid és a vízgőz, amik a reaktortérben részt vesznek a kedvező reakciók lejátszódásában, de a reaktort elhagyva ballasztként viselkednek. A gázosító közeg jelentősen befolyásolja a keletkező szintézisgáz kémiai összetételét és energiatartalmát, valamint az átalakítás hatékonyságát. A gázosító közeg segít lebontani a szilárd karbont és a nagyobb molekulatömegü szén-hidrogéneket, ami eredményeként hidrogén és szén-monoxid szabadul fel [2]. Leggyakrabban levegőt, vízgőzt, vagy tiszta oxigént alkalmazunk, de szén-dioxid és oxigén megfelelő arányú keveréke is ked- vező eredményt hozhat [2]. A helytelenül megválasztott segédgáz a technológia müködésképtelenségéhez vezethet.

A szintézisgázt hasznosítás elött célszerủ lehüteni, továbbá komplex tisztítási eljárásnak kell alávetni a káros- és a korrozív anyagok (kénsav és kén-dioxid) eltávolítása érdekében. A tisztított szintézisgázból rendszerint gázmotorban, vagy gázturbinában kombinált ciklusban elégetve villamos- és hőenergiát állítanak elő, de számottevő a vegyipari szintézisekben történő alkalmazása, föleg a metanol gyártásban [2].

A gázosítás önállóan nem létező technológia, mert az erre a célra kialakított reaktorban pirolízis és égetési zóna egyaránt kialakul. A megnevezés mégis helytálló, mert a lejátszódó reakciók termodinamikai egyensúly esetén, a sugárzási veszteségeket leszámítva, önfenntartó folyamatot eredményeznek [1]. Termodinamikai egyensúlyi állapotban a rendszer nem hül és nem melegszik, tehát nem igényel hőbetáplálást (pirolízis), vagy hőelvonást (égetés), valamint éghető szintézisgázt állít elő. A gázosítás négy lépcsőben valósul meg, ami a reaktorban eltérő hőmérsékletű és sztöchiometriai arányú zónákat eredményez. A zónák egymáshoz való viszonyát a reaktor típusa határozza meg [2].

A termikus kezelési technológiák közül a gázosítás az egyetlen, amely a légfelesleg tényező és a hőmérséklet függvényében lehet endoterm és exoterm folyamat [4]. A gázosítás alkalmazása során az önfenntartó folyamat elérése a cél [2]. Ez akkor következik be, ha a reaktor sugárzási és egyéb hőveszteségeit figyelembe véve, termodinamikai egyensúlyi állapotban üzemel. $\mathrm{Az}$ indítást követően az 5-20 perces tranziensfolyamat lefutása után a rendszer eléri, beáll egyensúlyi állapotba. A termodinamikai egyensúlyi állapotot a feladott alapanyag nedvességtartalma jelentősen befolyásolja. A légfelesleg tényező értékét a nedvességtartalom és a reaktor hö-veszteségei alapján lehet meghatározni [1]. 


\section{A termokinetikai modellvizsgá- latok alapegyenletei}

A termokinetikai modellvizsgálat során meghatározzuk az egyes alapanyagokból előállított gáztermékek kémiai és energetikai tulajdonságait. A folyamatok modellezésére termokinetikai modellt alkalmazzuk, ami a moláris tömeg- és energia megmaradás tételén alapul [1]. A modell alkalmazásával közelítő becslést lehet adni a keletkező gáz kémiai összetételére, fütőértékére, viszkozitására, és a lejátszódó kémiai reakciók energetikai hatékonyságára.

Mivel a modell lényege, hogy egyszerübbé és gyorsabbá tegye a számítást, ezért az egyszerüsített modellegyenletek felírásakor egyes összetevőket, mint például a nitrogén-oxidokat, valamint az etilén és acetilén vegyületeket elhanyagoltuk. A modellegyenlet a tüzelőanyag egy mólnyi karbontartalmára vonatkoztatott hidrogén- és oxigéntartalmára kerül felírásra $[\mathbf{1 , 5 , 6 ]}$.

A modellvizsgálatokat az egyensúlyi állandók módszerével, előre definiált elemi összetételü alapanyagra vonatkozóan, rögzített hőmérséklet és üzemi nyomás mellett végeztük el. Az egyensúlyi állandók módszere a megadott hőmérsékleten, az egyensúlyi átalakuláshoz tartozó számítás. Lényege, hogy a Gibbs-féle szabadenergia minimalizálásának elve alapján határozzuk meg a vizsgált folyamatok során keletkező termékek összetételét [7]. Az elemzések elkészítéséhez a Gaseq nevü, a NASAmódszeren alapuló szoftvert alkalmaztuk, amit Chris Morley fejlesztett ki és mindenki számára térítésmentesen elérhető, valamint szabadon felhasználható oktatási és nem profitorientált célokra. Elsősorban gázfázisú reagensek kölcsönhatását leíró egyenletek megoldására használható, de a termikus kezelési technológiák termokinetikai folyamatainak szimulálására is alkalmas. Abban az esetben, ha az elméleti és az alkalmazott moláris oxigénigény aránya egyenlő eggyel ( $\lambda=1)$, vagy egynél nagyobb, akkor visszakapjuk az égési egyenleteket.

A kibővített modellegyenlet a moláris anyagmegmaradás tétele alapján a következő módon írható fel (1):

$$
\begin{aligned}
& \mathrm{CH}_{k} \mathrm{O}_{l}+n_{m} \cdot \mathrm{H}_{2} \mathrm{O}+\mathrm{a} \cdot \mathrm{N}_{2}=x_{1} \cdot \mathrm{H}_{2}+x_{2} \\
& \mathrm{CO}+x_{3} \cdot \mathrm{H}_{2} \mathrm{O}+x_{4} \cdot \mathrm{CO}_{2}+x_{5} \cdot \mathrm{CH}_{4}+x_{6} \\
& \mathrm{O}_{2}+x_{7} \cdot \mathrm{NO}+x_{8} \cdot \mathrm{NO}_{2}+x_{9} \cdot \mathrm{N}_{2}+x_{10} \\
& \mathrm{~N}_{2} \mathrm{O}+x_{11} \cdot \mathrm{C}+x_{i} \cdot \mathrm{C}_{d} \mathrm{H}_{f} \mathrm{O}_{g}
\end{aligned}
$$

ahol: $\mathrm{n}_{\mathrm{m}}$ a tüzelőanyag egy mólnyi karbontartalmára vonatkoztatott nedvességtartalma; $a_{a}$ tüzelőanyag nitrogéntartalma, $x_{1} a$ keletkező nyers szintézisgáz moláris hidrogéntartalma, $x_{2}$ a szén-monoxidtartalma; $x_{3}$ a vízgőztartalma és $\mathrm{x}_{4}$ a szén-dioxidtartalma; $\mathrm{x}_{5}$ a metántartalom, $\mathrm{x}_{6}$ a maradó oxigéntartalom, $x_{7}$ a nitrogén-monoxid, $x_{8}$ a nitrogén-dioxid tartalom, $x_{9}$ a nitrogéntartalom; $\mathrm{x}_{10}$ a dinitrogén-oxid-tartalom; $\mathrm{x}_{11}$ a visszamaradt szilárd karbon; $\mathrm{x}_{\mathrm{i}}$ a keletkező egyéb összetevők moláris mennyisége (pl.: etilén, acetilén).

A modellvizsgálatok arra irányultak, hogy meghatározzuk a keletkező gáztermék kémiai összetételét, amiből származtatni tudjuk a technológiai-, valamint az energetikai hatékonyságot jellemző tulajdonságokat és paramétereket.

A paraméteres alapegyenletek megadása azért szükséges, mert ezeket felhasználva építettük fel a modellvizsgálatokat. A bemeneteli összetételek függvényében és a keletkező termékek ismeretében felírt (1) jelü képlet egyenlőségjelének jobb oldalán található ismeretlen mennyiségek meghatározására, azaz az egyenlet megoldására az egyensúlyi állandók módszerét választottuk.

Alkalmaztuk az egyensúlyi állandók módszerét, amihez előbb felírtuk minden egyes komponensre a moláris anyagmérleg egyenletet és ellenőriztük, hogy teljesül-e a moláris anyagmegmaradás tétele (2-4 öszszefüggések), végül meghatároztuk az egyensúlyi állandókat (5-6 képlet) [1, 6] . 
Karbon egyensúly:

$$
1=x_{2}+x_{4}+x_{5}
$$

Hidrogén egyensúly:

$$
k+2 \cdot n_{m}=2 \cdot x_{1}+2 \cdot x_{3}+4 \cdot x_{5} \text { (3) }
$$

Oxigén egyensúly:

$$
l+n_{m}=x_{2}+x_{3}+2 \cdot x_{4}+2 \cdot x_{6}
$$

Víz-gáz reakcióegyensúlyi állandó:

$$
K_{1}=\frac{x_{1} \cdot x_{4}}{x_{2} \cdot x_{3}}
$$

Metánképződési egyensúlyi állandó:

$$
K_{2}=\frac{x_{5}}{x_{1}^{2}}
$$

ahol: $K_{1}$ és $K_{2}$ a víz-gáz és a metánképződés egyensúlyi állandók, amelyek függnek a hőmérséklettől és a nyomástól.

Az egyes keletkező termékek moláris mennyiségben kifejezett értékét az egyensúlyi mól számmal (x) jelöljük. Az egyensúlyi mól szám megmutatja, hogy a keletkező komponens milyen mennyiségben keletkezik a többi termékkomponenshez képest.

A Gibbs-féle szabadenergia az egyensúlyi számok, a nyomás és a hőmérséklet függvényében a (7) képlet alapján írható fel $[1,8]$ :

$$
\frac{G}{R \cdot T}=\sum_{i=1}^{n}\left(\frac{x_{i} \cdot G_{i}^{0}}{R \cdot T}+x_{i} \cdot \ln \frac{x_{i}}{\sum x_{i}}+x_{i} \cdot \ln p\right)
$$

ahol: $\mathrm{G}$ a Gibbs-féle szabad energia, $\mathrm{G}_{\mathrm{i}}{ }^{0} \mathrm{az}$ i-edik alapanyag $1 \mathrm{~mol}$ anyag-mennyiségre vonatkoztatott fajlagos szabadenergiája atmoszférikus nyomáson, $\mathrm{R}$ az egyetemes gázállandó, $\mathrm{T}$ a rendszer hőmérséklete, $\mathrm{p}$ a rendszer nyomása, $\mathrm{x}_{\mathrm{i}}$ az i-edik komponens egyensúlyi mólszáma, azaz az i-edik alapanyag anyagmennyisége a keverékben, n a kémiai elemek száma, $\sum \mathrm{x}_{\mathrm{i}}$ a végtermék egyensúlyi mól számainak összege, a keverék anyagmennyisége.

Termodinamikai egyensúlyi állapotban a G/RT hányados minimalizálása a cél, amit az elemi összetétel határoz meg.
A modellvizsgálatok során a modellegyenletek megoldására a Gaseq szoftverben a rögzített nyomáson és hőmérsékleten vett egyensúlyi állandók módszerét alkalmaztuk. A szoftvert kémiai egyensúlyi folyamatok elemzése céljából fejlesztették ki, így használata megfelelő a termikus kezelési technológiák vizsgálatára. A gázosítási folyamatok szimulálásával megfigyelhettük, hogy a bemenő paraméterek változtatása hogyan befolyásolja a gázosítás során keletkező gáztermék összetételét.

\section{Energetikai hatékonyságvizsgálat}

Az energiahatékonyság napjaink egyik központi témája. Az energiahatékonysági politika szorosan kapcsolódik a kereskedelmi, az ipari versenyképesség, valamint az energiabiztonsági tevékenységekhez, de egyre fontosabbá vált a környezetvédelmi előnyök, mint a szén-dioxid kibocsátás csökkentésére irányuló törekvések egyik alapeszközeként [3]. Az energia átalakításának hatékonyságára számos hagyományos és nem konvencionális mérőszám ismert és alkalmazhatott. A következőkben három nem konvencionális paramétert mutatunk be.

A reakció-, vagy más néven a kémiai hatásfok (8) képlet megmutatja, hogy a szilárd tüzelőanyag energiatartalmának mekkora része jelenik meg az előállított gáztermékben $[9,10]$. A reakció hatásfok ismeretében meghatározható az égetés tökéletességét jellemző paraméter. Számítási módszerét a (9) képlet mutatja. Ezek alapján:

$$
\begin{gathered}
\eta_{r}=\frac{m_{g t} \cdot F_{g t}}{m_{s z t} \cdot F_{s z t}} \\
\eta_{\text {lé }}=1-\eta_{\mathrm{r}}
\end{gathered}
$$

ahol: $\prod_{\mathrm{r}}$ a reakció hatásfok, $\left(\mathrm{m}_{\mathrm{gt}}\right)$ a gáztermék tömegárama, $\mathrm{F}_{\mathrm{gt}}$ a gáztermék fütőérté$\mathrm{ke},\left(\mathrm{m}_{\mathrm{szt}}^{\cdot}\right)$ a szilárd tüzelőanyag tömegárama, $\mathrm{F}_{\mathrm{szt}}$ a tüzelőanyag fütőértéke és $\eta_{\mathrm{e}} \mathrm{az}$ égési hatásfok. 


\section{Akácfa gázosításának vizsgálata}

A tanulmány kivitelezése a korábban említett „Gaseq Chemical Equilibrium Program” segítségével, az egyensúlyi állandók módszerével történt. Egy adott elemzés lefuttatásához szükség van az adott folyamatot jellemző hőmérséklet, nyomás, valamint légfelesleg-tényező értékeire, és a választott tüzelőanyag összetételére. Ebben a feladatban tüzelőanyagként minden esetben akácfa szerepel. A száraz tüzelő-anyag öszszetételét az 1. táblázat tartalmazza.

1. táblázat. Akácfa elemi összetétele a száraz bázisra vonatkoztatva.

\begin{tabular}{|c|c|}
\hline Összetevő neve & Mennyisége \\
\hline Karbontartalom & $49,50 \%$ \\
\hline Hidrogéntartalom & $5,90 \%$ \\
\hline Oxigéntartalom & $43,30 \%$ \\
\hline Nitrogéntartalom & $0,40 \%$ \\
\hline Hamutartalom & $0,90 \%$ \\
\hline
\end{tabular}

A modellezés folyamata során azonban, nem az elemi összetevőket, hanem az elemi alkotó molekulákat kell megadni. A fa cellulóz molekulákból épül fel, amit a szoftver nem tartalmaz, ezért a cellulózt fenollal helyettesítettük. A korrigált összetételt a 2. táblázat tartalmazza.

2. táblázat. A fenol-tartalommal korrigált száraz akácfa tüzelöanyag összetétele.

\begin{tabular}{|c|c|}
\hline Összetevő neve & Mennyisége \\
\hline Karbontartalom & $0,000 \%$ \\
\hline Hidrogéntartalom & $1,746 \%$ \\
\hline Oxigéntartalom & $32,311 \%$ \\
\hline Nitrogéntartalom & $0,400 \%$ \\
\hline Hamutartalom & $0,900 \%$ \\
\hline Fenoltartalom & $64,644 \%$ \\
\hline
\end{tabular}

A fenti adatok meghatározása után a reakció (gázosítás) hatásfokának vizsgálatára került sor a (8) összefüggés alapján, különböző peremfeltételek mellett.

A hatásfok meghatározásához kiszámítottuk a felszabaduló éghető gázok elméleti fütőértékének, és a fa tényleges fütőértékének hányadosát. A felszabaduló gázok mennyiségét a fent említett Gaseq program segítségével határoztuk meg, az égéstermékben éghető alkotóként szén-monoxid és hidrogéngáz volt jelen a vizsgálat szempontjából számottevő mennyiségben.

Az elemzések során a légfeleslegtényező, a reakció hőmérséklet és az üzemi nyomás változtatására bekövetkező gázöszszetétel- és reakció-hatásfok változását vizsgáltuk.

Jelen szimuláció során a hőmérsékletet $600{ }^{\circ} \mathrm{C}$ és $1.000{ }^{\circ} \mathrm{C}$ fok között 100 -as léptékkel, valamint a nyomást 1-20 bar között 5-ös léptékkel végeztük el. Az adatokat a következő táblázatokban foglaltuk össze, majd diagramon ábrázoltuk. A vizsgálat során az akácfa nedvességtartalmát konstans 15\%-nak vettük, a légfelesleg-tényezőt pedig 0,5-nek állítottuk be. Minden esetben 1 kg akácfa gázosítását vizsgáltuk.

3. táblázat. $600{ }^{\circ} \mathrm{C}$ hömérsékleten kapott hidrogén és szén-monoxid mennyiségek.

\begin{tabular}{|c|c|c|}
\hline $\begin{array}{c}\text { Nyomás } \\
\text { [bar] }\end{array}$ & $\begin{array}{c}\text { Hidrogén- } \\
\text { tartalom [kg] }\end{array}$ & $\begin{array}{c}\text { Szén- } \\
\text { monoxid- } \\
\text { tartalom [kg] }\end{array}$ \\
\hline 1 & 0,03700 & 0,38466 \\
\hline 5 & 0,02339 & 0,19235 \\
\hline 10 & 0,01809 & 0,13551 \\
\hline 15 & 0,01539 & 0,11033 \\
\hline 20 & 0,01367 & 0,09534 \\
\hline
\end{tabular}

4. táblázat. $600{ }^{\circ} \mathrm{C}$ hömérsékleten kapott fütöérték és reakció hatásfok.

\begin{tabular}{|c|c|c|}
\hline $\begin{array}{c}\text { Nyomás } \\
\text { [bar] }\end{array}$ & $\begin{array}{c}\text { Fagáz fütőér- } \\
\text { téke [MJ/kg] }\end{array}$ & $\begin{array}{c}\text { Reakció } \\
\text { hatásfok [\%] }\end{array}$ \\
\hline 1 & 8,3251 & 70,3682 \\
\hline 5 & 4,7495 & 40,1458 \\
\hline 10 & 3,5395 & 29,9174 \\
\hline 15 & 2,9611 & 25,0292 \\
\hline 20 & 2,6033 & 22,0049 \\
\hline
\end{tabular}


A 3. táblázatban megfigyelhető, hogy kis hőmérsékleten végzett gázosítás során az üzemi nyomás növekedése csökkenti a hidrogén- és a szén-monoxid-termelést, amely következtében a felszabaduló fagáz fütőértéke csökken és a reakció hatásfoka drasztikusan romlik (4. táblázat).

$\mathrm{Az}$ 5. és a 6. táblázat $700{ }^{\circ} \mathrm{C}$ hőmérséklet esetében szemlélteti a kapott eredményeket. A nyomás növelésének függvényében szintén energetikai hatékonyságcsökkenés figyelhető meg, azonban a csökkenés meredeksége kisebb értékü.

5. táblázat. $700{ }^{\circ} \mathrm{C}$ hömérsékleten kapott hidrogén és szén-monoxid mennyiségek.

\begin{tabular}{|c|c|c|}
\hline $\begin{array}{c}\text { Nyomás } \\
\text { [bar] }\end{array}$ & $\begin{array}{c}\text { Hidrogén- } \\
\text { tartalom [kg] }\end{array}$ & $\begin{array}{c}\text { Szén- } \\
\text { monoxid- } \\
\text { tartalom [kg] }\end{array}$ \\
\hline 1 & 0,03740 & 0,48279 \\
\hline 5 & 0,03409 & 0,44707 \\
\hline 10 & 0,02950 & 0,39625 \\
\hline 15 & 0,02611 & 0,35773 \\
\hline 20 & 0,02362 & 0,32876 \\
\hline
\end{tabular}

6. táblázat. $700{ }^{\circ} \mathrm{C}$ hömérsékleten kapott fütöérték és reakció hatásfok.

\begin{tabular}{|c|c|c|}
\hline $\begin{array}{c}\text { Nyomás } \\
\text { [bar] }\end{array}$ & $\begin{array}{c}\text { Fagáz fütőér- } \\
\text { téke [MJ/kg] }\end{array}$ & $\begin{array}{c}\text { Reakció } \\
\text { hatásfok [\%] }\end{array}$ \\
\hline 1 & 9,3642 & 79,1514 \\
\hline 5 & 8,6062 & 72,7445 \\
\hline 10 & 7,5421 & 63,7503 \\
\hline 15 & 6,7463 & 57,0233 \\
\hline 20 & 6,1549 & 52,0245 \\
\hline
\end{tabular}

A 7. és a 8. táblázat $800{ }^{\circ} \mathrm{C}$ hőmérsékleten végzett gázosításra vonatkozóan tartalmazza a kapott eredményeket. A nyomás növelésének hatására bekövetkező energetikai hatékonyság-romlás egyre csökken. Míg $600{ }^{\circ} \mathrm{C}$-on a reakció hatásfok 20 bar üzemi nyomáshoz képest kevesebb, mint a harmadára csökkent 1 bar üzemi nyomáson történő vizsgálatokhoz képest, addig $800^{\circ} \mathrm{C}$ nál ez az érték már a 10\%-ot sem érte el.
7. táblázat. $800^{\circ} \mathrm{C}$ hömérsékleten kapott hidrogén és szén-monoxid mennyiségek.

\begin{tabular}{|c|c|c|}
\hline $\begin{array}{c}\text { Nyomás } \\
\text { [bar] }\end{array}$ & $\begin{array}{c}\text { Hidrogén- } \\
\text { tartalom [kg] }\end{array}$ & $\begin{array}{c}\text { Szén- } \\
\text { monoxid- } \\
\text { tartalom [kg] }\end{array}$ \\
\hline 1 & 0,03438 & 0,52939 \\
\hline 5 & 0,03412 & 0,52648 \\
\hline 10 & 0,03339 & 0,51837 \\
\hline 15 & 0,03240 & 0,50705 \\
\hline 20 & 0,03129 & 0,49426 \\
\hline
\end{tabular}

8. táblázat. $800^{\circ} \mathrm{C}$ hömérsékleten kapott fütöérték és reakció hatásfok.

\begin{tabular}{|c|c|c|}
\hline $\begin{array}{c}\text { Nyomás } \\
\text { [bar] }\end{array}$ & $\begin{array}{c}\text { Fagáz fütőér- } \\
\text { téke [MJ/kg] }\end{array}$ & $\begin{array}{c}\text { Reakció } \\
\text { hatásfok [\%] }\end{array}$ \\
\hline 1 & 9,4724 & 80,0664 \\
\hline 5 & 9,4118 & 79,5543 \\
\hline 10 & 9,2423 & 78,1215 \\
\hline 15 & 9,0092 & 76,1509 \\
\hline 20 & 8,7468 & 73,9331 \\
\hline
\end{tabular}

9. táblázat. $900{ }^{\circ} \mathrm{C}$ hömérsékleten kapott hidrogén és szén-monoxid mennyiségek.

\begin{tabular}{|c|c|c|}
\hline $\begin{array}{c}\text { Nyomás } \\
\text { [bar] }\end{array}$ & $\begin{array}{c}\text { Hidrogén- } \\
\text { tartalom [kg] }\end{array}$ & $\begin{array}{c}\text { Szén- } \\
\text { monoxid- } \\
\text { tartalom [kg] }\end{array}$ \\
\hline 1 & 0,03179 & 0,56572 \\
\hline 5 & 0,03176 & 0,56542 \\
\hline 10 & 0,03168 & 0,56455 \\
\hline 15 & 0,03156 & 0,56318 \\
\hline 20 & 0,03140 & 0,56132 \\
\hline
\end{tabular}

10. táblázat. $900{ }^{\circ} \mathrm{C}$ hömérsékleten kapott fütöérték és reakció hatásfok.

\begin{tabular}{|c|c|c|}
\hline $\begin{array}{c}\text { Nyomás } \\
\text { [bar] }\end{array}$ & $\begin{array}{c}\text { Fagáz fütőér- } \\
\text { téke [MJ/kg] }\end{array}$ & $\begin{array}{c}\text { Reakció } \\
\text { hatásfok [\%] }\end{array}$ \\
\hline 1 & 9,5286 & 80,5409 \\
\hline 5 & 9,5219 & 80,4849 \\
\hline 10 & 9,5036 & 80,3294 \\
\hline 15 & 9,4753 & 80,0908 \\
\hline 20 & 9,4373 & 79,7697 \\
\hline
\end{tabular}


A 9. és a 10. táblázatok $900{ }^{\circ} \mathrm{C}$ hömérsékleten végzett gázosítás eredményeit tartalmazza. Megfigyelhető, hogy itt már a nyomásnövelés hatására bekövetkező reakcióhatásfok-romlás az 1\%-ot sem éri el.

$1.000{ }^{\circ} \mathrm{C}$ hőmérsékleten végzett gázosításnál (11. és 12. táblázatok) a nyomásnövelés hatása elhanyagolható.

A kapott eredmények alapján elmondható, hogy állandó légfelesleg-tényező mellett az üzemi nyomás növelése a gázosítás reakció hatásfokának csökkenését eredményezi, az alkalmazott hőmérséklet azonban pozitív irányban befolyásolja. A hőmérséklet függvényében figyelembe vett nyomásnövekedés reakcióhatásfok-csökkentő hatása exponenciális jelleget mutat. Az ideális gázosítási hőmérséklet akácfa esetében $800{ }^{\circ} \mathrm{C}$ és $900{ }^{\circ} \mathrm{C}$ közé tehető.

11. táblázat. $1.000{ }^{\circ} \mathrm{C}$ hömérsékleten kapott hidrogén és szén-monoxid mennyiségek.

\begin{tabular}{|c|c|c|}
\hline $\begin{array}{c}\text { Nyomás } \\
\text { [bar] }\end{array}$ & $\begin{array}{c}\text { Hidrogén- } \\
\text { tartalom [kg] }\end{array}$ & $\begin{array}{c}\text { Szén- } \\
\text { monoxid- } \\
\text { tartalom [kg] }\end{array}$ \\
\hline 1 & 0,02967 & 0,59522 \\
\hline 5 & 0,02966 & 0,59516 \\
\hline 10 & 0,02964 & 0,59503 \\
\hline 15 & 0,02962 & 0,59482 \\
\hline 20 & 0,02960 & 0,59454 \\
\hline
\end{tabular}

12. táblázat. $1.000{ }^{\circ} \mathrm{C}$ hömérsékleten kapott fütöérték és reakció hatásfok.

\begin{tabular}{|c|c|c|}
\hline $\begin{array}{c}\text { Nyomás } \\
\text { [bar] }\end{array}$ & $\begin{array}{c}\text { Fagáz fütőér- } \\
\text { téke [MJ/kg] }\end{array}$ & $\begin{array}{c}\text { Reakció } \\
\text { hatásfok [\%] }\end{array}$ \\
\hline 1 & 9,5721 & 80,9090 \\
\hline 5 & 9,5703 & 80,8937 \\
\hline 10 & 9,5666 & 80,8624 \\
\hline 15 & 9,5621 & 80,8241 \\
\hline 20 & 9,5569 & 80,7800 \\
\hline
\end{tabular}

Az elmondottakat az 1. ábra szemlélteti. Megfigyelhető, hogyan alakul a reakció hatásfok a gázosítási hőmérséklet és az üzemi nyomás függvényében. Látható, hogy kisebb hőmérsékleten az üzemi nyomás nagyobb hatást gyakorol a gázosítás reakció hatásfokára, mint nagyobb hőmérsékleten.

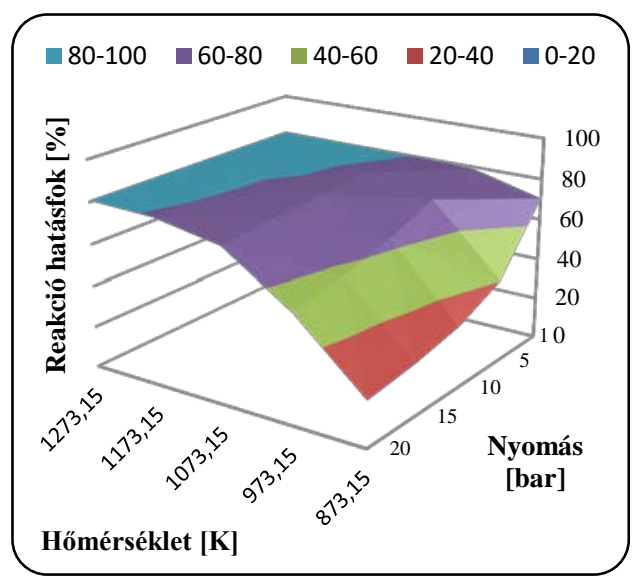

1. ábra. Reakció hatásfok a hömérséklet és a nyomás függvényében, akácfa gázosítása során.

Megvizsgáltuk az is, hogyan változik a reakció hatásfok állandó légfelesleg tényező és hömérséklet mellett, valamint állandó nedvességtartalmú tüzelőanyag esetében. A 2. ábra szemlélteti, hogyan változik a nyomás függvényében a reakció hatásfoka 0,6 légfelesleg tényezőnél, $800{ }^{\circ} \mathrm{C}$ hőmérsékleten végzett gázosítás során, a 15\% az elgázosított akácfa nedvességtartalma.

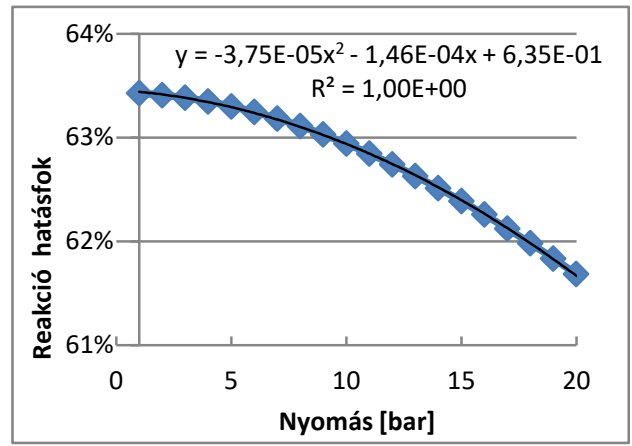

2. ábra. Reakció hatásfok a nyomás függvényében, állandó hömérséklet, légfelesleg tényezö és nedvességtartalom esetén. 
Megfigyelhető, hogy a nyomás növelése exponenciális jelleggel csökkenti a reakció hatásfokát, tehát gázosítás során célszerütlen magas nyomást választani a reakció színterén. Hasonló tendencia figyelhető meg változó légfelesleg tényező, hőmérséklet és nedvességtartalom esetén.

Következő lépésként megvizsgáltuk, hogyan változik a reakció hatásfoka, ha a légfelesleg-tényező értéke, illetve a tüzelőanyag nedvességtartalma változik, amenynyiben a gázosítás hömérséklete $800{ }^{\circ} \mathrm{C}$ és az üzemi nyomás 1 bar.

Megfigyelhető, hogy a légfeleslegtényező növelésével a reakció hatásfoka drasztikusan csökken. A tüzelöanyag nedvességtartalmának növekedése pedig csak kis mértékben csökkenti a reakció hatásfokát. Mindezt a 13. táblázat és a 3. ábra szemlélteti.

13. táblázat. $800{ }^{\circ} \mathrm{C}$ hömérsékleten és 1 bar üzemi nyomás mellett végzett gázosításra vonatkozó reakció hatásfokok.

\begin{tabular}{|c|c|c|c|}
\hline $\begin{array}{c}\text { Nedv.- } \\
\text { tartalom }\end{array}$ & \multicolumn{3}{|c|}{ Légfelesleg-tényezö [-] } \\
\hline$[\%]$ & 0,5 & 0,6 & 0,7 \\
\hline 10 & $80,10 \%$ & $63,65 \%$ & $48,14 \%$ \\
\hline 20 & $79,49 \%$ & $63,19 \%$ & $47,77 \%$ \\
\hline 25 & $79,16 \%$ & $62,93 \%$ & $47,58 \%$ \\
\hline
\end{tabular}

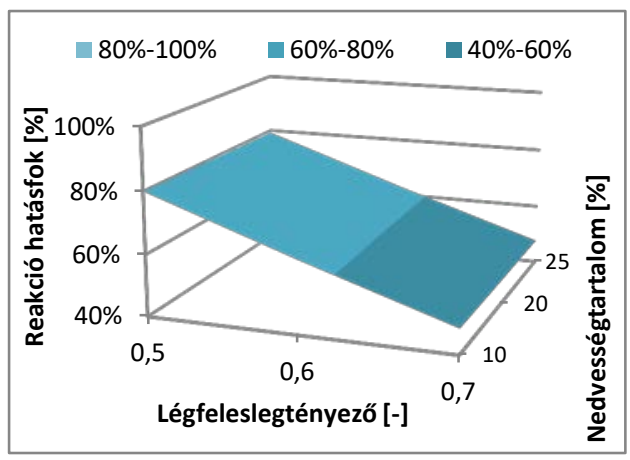

3. ábra. A hatásfok alakulása a légfeleslegtényezó és a nedvességtartalom függvényében $800^{\circ} \mathrm{C}$ hömérsékleten.
Az elemzés legvégén pedig azt vizsgáltuk meg, hogyan viszonyul a nedves fa gázosítása során előállított szintézisgázból, gázmotor segítséggel termelt villamosenergia, ahhoz az energiamennyiséghez, amelyet a nedves fa elégetésével, gőzturbinás erőműben nyernénk. Ezt a mennyiséget villamosenergia-sürüségváltozásnak neveztük el. A számítási módszerét a 10. összefüggés mutatja.

$$
\Delta \mathrm{e}_{\mathrm{v}}=\frac{e_{k \text { gázosítás }} \cdot \eta_{\text {egv D }}}{e_{k \text { égetés }} \cdot \eta_{\text {egv RC }}},
$$

ahol: $\Delta \mathrm{e}_{\mathrm{rv}}$ a villamosenergia-sürüségváltozás, $e_{k}$ gázosítás a gázosítás fajlagos energia kihozatala, $e_{k}$ égetés az égetés fajlagos energia kihozatala, $\eta_{\text {egv } \mathrm{D}}$ a gázosítás során alkalmazott Diesel-körfolyamat villamos hatásfoka, $\eta_{\text {egv RC az égetés során }}$ alkalmazott Rankine-Clausisu-körfolyamat villamos hatásfoka.

A Rankine-Clausius ciklus villamos hatásfokát 27\%-nak, míg a gázmotoros energiatermelés villamos hatásfokát 36\%-nak vettük, amely értékek átlagosnak tekinthetőek. Az így kapott értékeket diagramon ábrázoltam (4. ábra).

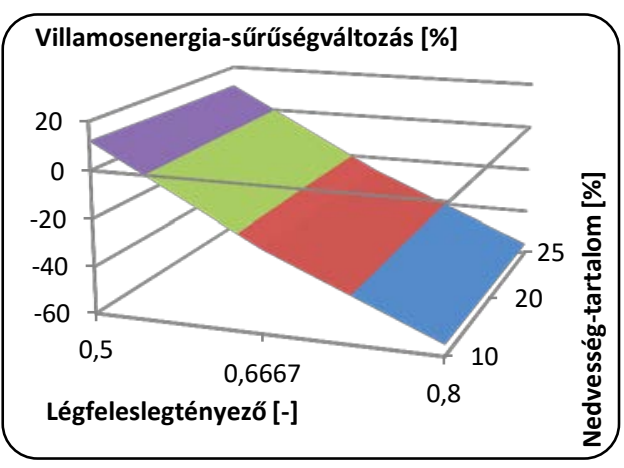

4. ábra. A villamosenergia-sürüségváltozás alakulása a légfelesleg-tényezö és a nedvességtartalom függvényében $800{ }^{\circ} \mathrm{C}$ hömérsékleten.

A 4. ábráról leolvasható, hogy mind a légfelesleg tényező, mind a nedvességtarta- 
lom növekedésével az energiasürüségváltozás kedvezőtlen irányba változik. A légfelesleg tényező növelése intenzívebb villamosenergia-sürüségváltozást eredményez, mint a nedvességtartalom növekedése, ezért nagyobb nedvességtartalmú tüzelőanyag esetében is kedvező lehet a gázosításon alapuló villamosenergia-termelés.

0,5-ös légfelesleg tényező felett pedig az energiasürüség-változás értéke negatívvá válik, ami azt eredményezi, hogy egységnyi tüzelöanyagból nem lehet több villamos energiát előállítani gázosítási technológia alkalmazásával, mint a hagyományos égetéses technikával.

\section{Következtetések}

Az elemzések során megbizonyosodtunk arról, hogy a fás szárú biomasszák gázosításának szimulációja mögött rendkívül bonyolult számítások állnak. Továbbá az is nyilvánvalóvá vált számunkra, hogy az alapanyag tulajdonságai közül vizsgált nedvességtartalom, valamint a technológiához kapcsolódó paraméterek közül a légfelesleg-tényező, a hőmérséklet, valamint a nyomás változtatása nagymértékben tudja befolyásolni az előállított szintézisgáz fütőértékét. Az elemzés arra mutatott rá, hogy a nedvességtartalom, a légfelesleg-tényező, valamint a nyomás növelése a reakció hatásfok csökkenését eredményezi, míg a hőmérséklet emelése a reakció hatásfok növekedéséhez járul hozzá.

A fenti eredményekből megállapítható tehát, hogy a gázosítás hatásfoka a három vizsgált légfelesleg-tényező közül 0,5 értéken a legmagasabb. Mivel a nedvességtartalom nem befolyásolja jelentősen a gázosítás hatásfokát, ezért jól alkalmazható olyan esetekben is, ahol a tüzelőanyag nedvességtartalma viszonylag magas (20-25\%).

A nyomás növekedésével a hatásfok exponenciálisan csökken, ezért nem célszerü magas nyomást választani a gázosítás reakcióterében. A reakciótér hőmérséklete 800
${ }^{\circ} \mathrm{C}$ feletti növelése csekély mértékben javítja a reakció hatásfokát, ezért növelése gazdaságossági megfontolások alapján nem célszerü.

Véleményünk szerint tehát egy-egy adott gázosító üzem hatékony müködtetése rendkívül összetett folyamatnak minősül és gondos mérnöki munkát igényel.

\section{Szakirodalmi hivatkozások}

[1] Zainal Z. A., Ali R., Lean C. H., Seetharamu K. N.: Prediction of perfor-mance of $a$ downdraft gasifier using equilibrium modelling for different biomass material. Energy Conversion and Management 42. (2001) 1499-1515.

[2] Red T. B., Das A.: Handbook of biomass downdraft gasifier engine systems. Solar Energy Research Ins., 1988. 148.

[3] Hill T. \& Dowen, S.: Pyrolysis and gasification. Briefing (Draf 2), UK Without Incineration Network (UK WIN), 2010. 1-9.

[4] Patterson, M. G.: What is energy efficiency? Concepts, indicators and methodological issues. Energy Policy. Vol. 24, No. 5. 1996. 377-390.

[5] Wang Y., Kinoshita, C. M.: Kinetic model of biomass gasification. Solar Energy, Vol. 51. No. 1. 1993, 19-25.

[6] Mountouris, A., Voutsas, E., Tassios, D.: Solid waste plasma gasification: equilibrium model development and exergy analysis. Energy Conversion and Management. Vol. 47. 2006. 1723-1737.

[7] Hatzilyberis, K. S.: Design of an indirect heat rotary kiln gasifier. Fuel Processing Technology. 92, 2011. 2429-2454.

[8] Morly, C.: Method for calculating equilibrium compositions at specified temperature. Gaseq, a chemiacal equilibrium program for windows. www.gaseq.co.uk 2005. 6.

[9] Rajvanshi, K., A.: Biomass gasification. Alternative Energy in Agriculture. Vol. 2. No. 4. 1986. 83-102.

[10] Schuster, G., Löffer, G., Weigel, K., Hofbauer, H.: Biomass steam gasification an extensive parametric modeling study. Bioresource Technology. Vol. 77. 2001. 71-79. 